\title{
Cytodiagnosis of Tubercular Dactylitis with Skin and Lymph Node Lesions in an Immunocompetent Patient
}

Smita Mahapatra ${ }^{1 *}$, Sitaram Mahapatra1, Pallavi Bhuyan', Kaumudee Pattnaik ${ }^{1}$ and Ashoka Mahapatra²

${ }^{1}$ Department of Pathology, S.C.B. Medical College, Cuttack, Odisha, India

${ }^{2}$ Department of Microbiology, S.C.B. Medical College, Cuttack, Odisha, India

\begin{abstract}
Tubercular dactylitis is an extremely rare entity. To the best of our knowledge, we are reporting for the first time tuberculosis of phalanx along with cutaneous nodule and lymph nodes in an immunocompetent patient even in absence of a detectable primary focus. A 35 year old male presented with a hard swelling in proximal phalanx of left ring finger. He had a cutaneous nodule on right index finger and enlarged epitrochlear and axillary lymph nodes on the ipsilateral side. In X- Ray, a lytic lesion destroying whole proximal phalanx was seen with chest X- Ray being normal. HIV ELISA was negative. Cytology from cutaneous nodule and lymph nodes depicted the picture of a granulomatous lesion. Biopsy, culture of bone tissues and polymerase chain reaction confirmed the lesions to be tubercular. Tubercular dactylitis along with other tubercular lesions is an extremely rare condition and the lesions must be differentiated from other granulomatous conditions to advocate specific therapy.
\end{abstract}

Keywords: Tubercular dactylitis; Cutaneous nodule; Lymph node

\section{Introduction}

Tubercular involvement of phalanx is an unusual presentation [1,2]. In skeletal involvement, spine is the most frequent site [3]. Tubercular dactylitis, although most frequently encountered in children, also occurs in adults [4]. Tubercular lesions taken together in an immunocompetent patient involving phalanx, cutaneous nodule, axillary and epitrochlear lymph nodes has not been yet reported in the literature although, tubercular dactylitis along with cutaneous involvement has already been established [5]. In our case, there was tubercular involvement of multiple sites without any pulmonary involvement in an HIV negative patient.

\section{Case Report}

A 35-year-old male presented with a hard swelling of $2 \mathrm{~cm}$ diameter involving proximal phalanx of left ring finger of 2 months duration (Figure 1). On examination, there was also a cutaneous nodule of $0.5 \mathrm{~cm}$, over the base of right index finger and had enlarged, mobile epitrochlear and axillary lymph nodes of about $2 \mathrm{~cm}$, on the ipsilateral side. There was no history of recent trauma to the finger, fever, weight loss, cough and tingling sensation. On examination, he had no hypopigmented patch or nerve thickening.

All the hematological parameters were within normal limits besides raised ESR of $90 \mathrm{~mm}$ in $1^{\text {st }} \mathrm{Hr}$ (Westergren) and Mantoux test of 25 $\mathrm{mm}$. Sickling test was negative. X- Ray revealed lytic lesion destroying whole proximal phalanx of left ring finger (Figure 2). Chest X- Ray was normal. X- Ray of right hand revealed no bony abnormality and it was a soft tissue swelling. Blood, throat swab and urine cultures were sterile. Multiple Ziehl-Neelsen (Z-N) stain of induced sputum samples was negative for acid- fast bacilli. Rheumatology serology (ANA, Antids DNA, P- ANCA, C- ANCA), syphilis serology, HIV ELISA was negative.

In Fine Needle Aspiration (FNA) of proximal phalanx of left ring finger swelling revealed epithelioid cell clusters, caseating necrosis, multinucleated giant cells and few osteoblasts (Figure 3). FNA of both epitrochlear and axillary lymph nodes showed caseating necrosis, epithelioid cells and Langhans giant cells in the background of lymphoid cells and cutaneous nodule had a similar picture of granulomatous

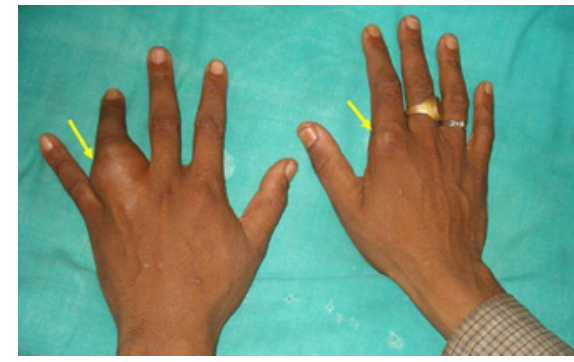

Figure 1: A swelling in proximal phalanx of left ring finger and a subcutaneous nodule over base of right index finger.

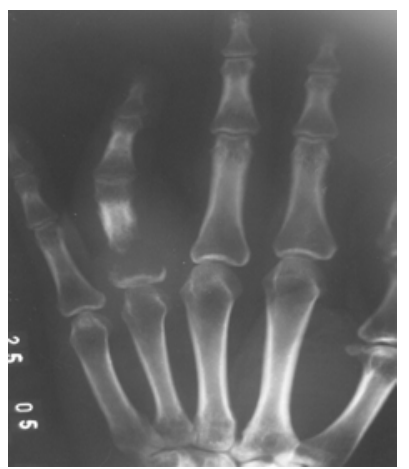

Figure 2: X-Ray of left hand showing lytic lesion destroying proximal phalanx of left ring finger.

*Corresponding author: Smita Mahapatra, Department of Pathology, S.C.B. Medical College, Cuttack, Odisha, India, 751015, Tel: 91-9437094138; E-mail: doctorsmita@rediffmail.com

Received May 19, 2012; Accepted June 29, 2012; Published July 02, 2012

Citation: Mahapatra S, Mahapatra S, Bhuyan P, Pattnaik K, Mahapatra A (2012) Cytodiagnosis of Tubercular Dactylitis with Skin and Lymph Node Lesions in an Immunocompetent Patient. J Cytol Histol 3:147. doi:10.4172/2157-7099.1000147

Copyright: $\odot 2012$ Bhuyan $\mathrm{P}$, et al. This is an open-access article distributed under the terms of the Creative Commons Attribution License, which permits unrestricted use, distribution, and reproduction in any medium, provided the original author and source are credited. 
Citation: Mahapatra S, Mahapatra S, Bhuyan P, Pattnaik K, Mahapatra A (2012) Cytodiagnosis of Tubercular Dactylitis with Skin and Lymph Node Lesions in an Immunocompetent Patient. J Cytol Histol 3:147. doi:10.4172/2157-7099.1000147

lesion. But, Z-N stain of cytoaspirate was negative for acid- fast bacilli. Finally, cytological diagnosis of granulomatous lesion was made.

The patient was advised for incisional biopsy of the affected left finger swelling. Grossly, multiple bits of yellowish tissues were received. Microscopically, granulomas consisting of caseating necrosis, epithelioid cells, Langhans giant cells, lymphocytes were noticed (Figure 4). Hence, a diagnosis of tubercular dactylitis was made. Biopsy from cutaneous nodule and lymph nodes (Figure 5) had a similar picture of tubercular lesions. Periodic acid schiff stain for fungus was negative. Biopsy tissue from phalanx was simultaneously sent for culture of tubercle bacilli and Polymerase Chain Reaction (PCR) study. The PCR came as positive on $7^{\text {th }}$ day. At the end of $3^{\text {rd }}$ week typical buff colored colonies grew on Lowenstein Jenson (LJ) slope (Figure 6)

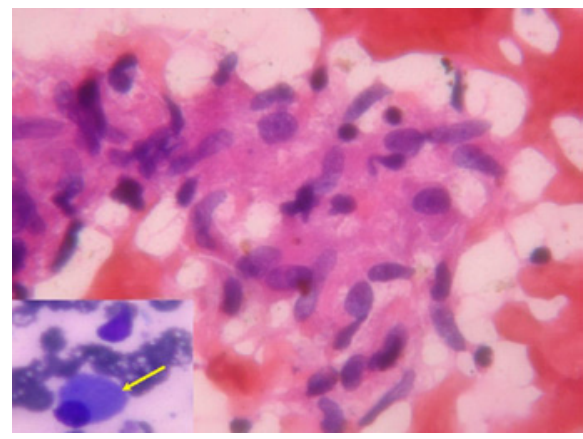

Figure 3: Cytosmear showing epithelioid cell clusters. Insert showing an osteoblast (MGG, X 400).

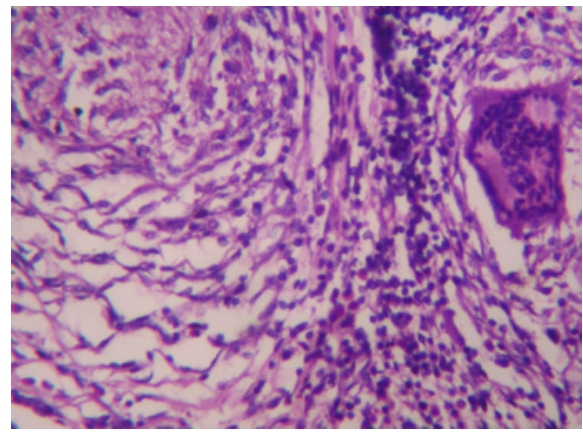

Figure 4: Photomicrograph of phalanx showing granuloma comprising of circumscribed area with caseating necrosis, epithelioid cells, multinucleated giant cell and peripheral collar of lymphocytes (HE, X400).

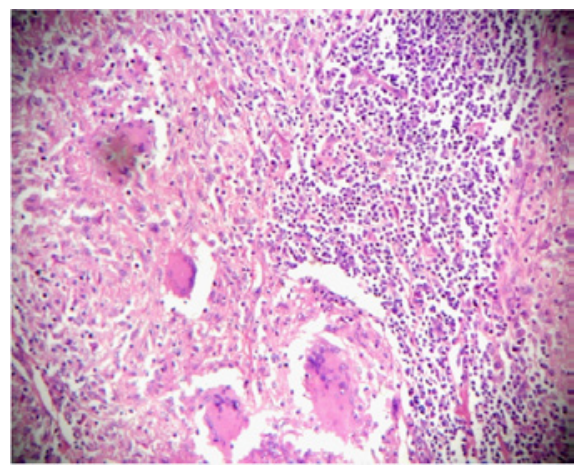

Figure 5: Photomicrograph of lymph node showing granuloma with epithelioid cells, Giant Cells (HE, X400).

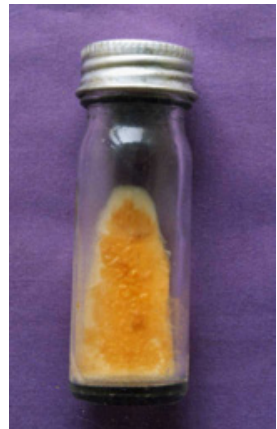

Figure 6: LJ Slope showing buff coloured colonies of Mycobacterium tuberculosis.

which was identified to be Mycobacterium tuberculosis as per standard procedures [6]. So, finally the diagnosis was confirmed to be tubercular dactylitis. Antituberculous Treatment (ATT) was initiated and there was marked improvement within three months of treatment. The patient was advised to continue ATT till $12^{\text {th }}$ month and routine follow up.

\section{Discussion}

Tuberculosis of bone is less common than the pulmonary form and involvement of phalanx is infrequent [1,2]. In skeletal tuberculosis, spine is the most common site [3]. After thorough search from literatures, we have concluded that we are reporting a patient presenting with tuberculosis of phalanx, cutaneous nodule and lymph nodes which is first of its kind. Another important feature was the immunocompetence of the patient.

Tuberculosis of bone occurs due to hematogenous dissemination during florid phase of primary complex which become clinically evident years later [5]. Some believe in "Lociminoris resistentiae" theory in which dormant infected foci are reactivated with decrease local resistance [7]. Still others believe in sporadic dissemination from a quiescent primary or extra- osseous focus.

Tuberculosis of phalanx although more common in children, also occurs in adults. Our case was an adult with X-Ray showing lytic lesion of phalanx. Both cytology and histology revealed caseating necrosis, epithelioid cells, and few multinucleated giant cells. Absence of soft tissue swelling and necrosis ruled out syphilis. Absence of peripheral nerve involvement, hypopigmented patches and plenty of foamy macrophages, presence of caseating necrosis excluded leprosy [8]. Negative fungal stain, along with bone destruction with no new bone formation differentiated it from fungal (Coccidiomycosis, Blastomycosis) dactylitis. In fungal dactylitis, granuloma most commonly yield staphylococci / streptococci $[9,10]$.

PCR study increase sensitivity and allow exclusion of nontuberculous mycobacteria (M. marium). The gold standard for osseous tuberculosis diagnosis is culture of Mycobacterium tuberculosis from bone tissues [11]. Current recommended treatment for osseous tuberculosis is 2 months treatment with isoniazide, rifampin, pyrozinamide and ethambutol followed by 6 to 12 month regimen of isoniazide and rifampin.

\section{Conclusion}

Tubercular dactylitis along with involvement of cutaneous nodule and lymph nodes is very rare in its manifestation. A critical and 
Citation: Mahapatra S, Mahapatra S, Bhuyan P, Pattnaik K, Mahapatra A (2012) Cytodiagnosis of Tubercular Dactylitis with Skin and Lymph Node Lesions in an Immunocompetent Patient. J Cytol Histol 3:147. doi:10.4172/2157-7099.1000147

Page 3 of 3

accurate dissection of the differential diagnosis is of utmost importance to advocate an early specific therapy.

\section{References}

1. Subasi M, Bukte Y, Kapukaya A, Gurkan F (2004) Tuberculosis of metacarpals and phalanges of the hand. Ann Plast Surg 53: 469-472.

2. Karnas YL, Yim KK (1998) Mycobacterium tuberculosis infection of the hand: a case report and review of the literature. Ann Plast Surg 40: 65-67.

3. Evanchick CC, Davis DE, Harrington TM (1986) Tuberculosis of peripheral joints: an often missed diagnosis. J Rheumatol 13: 187-191.

4. Feldman F, Auerbach R, Johnston A (1971) Tuberculous dactylitis in the adult. Am J Roentgenol Radium Ther Nucl Med 112: 460-479.

5. Graham- Brown RA, Sarkany I (1980) Lichen scrofulosorum with tuberculosis dactylitis. Br J Dermatol 103: 561-564

6. Mackie TJ, Collee JG, McCartney JE (1989) Mackie and McCartney practical medical microbiology. (14thedn), Churchill Livingstone, NewYork 329-412.

7. Poppel MH, Lawrence LR, Jacobson HG, Stein J (1953) Skeletal tuberculosis: a roentgenographic survey with reconsideration of diagnostic criteria. Am J Roentgenol Radium Ther Nucl Med 70: 936-963.

8. Dave S, Nori AV, Thappa DM, Siddaraju N (2004) Leprous osteitis presenting as bone cyst and erosions. Dermatol Online J 10: 17

9. Kelly PJ, Weed LA, Lipscomb PR (1963) Infection of tendon sheaths, bursae and soft tissues by acid fast bacilli other than tubercule bacilli. J Bone Join Surg Am 45-A: 327-336

10. Kelly PJ, Karlson AG, Weed LA, Lipscomb PR (1967) Infection of synovia tissue by mycobacteria other than Mycobacterium tuberculosis. J Bone Join Surg Am 49: 1521-1530.

11. In Reichman LB, Hershfield ES (2000) Tuberculosis: a comprehensive international approach. New York, Marcel Dekker 149-165. 